\title{
The impact of Trans-Pacific Partnership agreement on the Canadian economy
}

\author{
Kakali Mukhopadhyay ${ }^{1,2^{*}}$ and Paul J. Thomassin ${ }^{2}$
}

\author{
*Correspondence: \\ kakali.mukhopadhyay@ \\ mcgill.ca; kakali@gipe.ac.in \\ ${ }^{1}$ Gokhale Institute \\ of Politics and Economics, \\ Pune 411104, India \\ Full list of author information \\ is available at the end of the \\ article
}

\begin{abstract}
The Trans-Pacific Partnership is the most comprehensive trade agreement in the world. The TPP will help deepen Canada's trade ties in the dynamic and fast growing Asia-Pacific region while strengthening existing economic partnerships with NAFTA partners and across Americas. The TPP will eliminate tariffs on almost all of Canada's key exports and offer access to new opportunities in the Asia-Pacific region. Tariffs and other barriers on a wide range of Canadian products from various sectors will be reduced, including in agriculture and agri-food, fish and seafood, forestry and wood products, metals and mining and industrial goods. These benefits can only be derived if USA ratifies it. However, the US president has already signed a presidential memorandum confirming the US withdrawal from the TPP agreement. With this background, the current study evaluates the economic impacts of the Trans-Pacific Partnership agreements on the Canadian economy by the year 2030 using a global CGE framework. The study undertakes a number of simulations based on the level of tariff reduction across selected commodities between Canada and other TPP Nations. The GTAP 9 Data Base with the reference year of 2011 is used for the study. Results show that Canada stands to benefit significantly from improved access to the TPP region. Canada expects a considerable increase in agricultural export. Canola, processed food and beverages, seafood, beef and pork sectors are expected to benefit from the deal. Industrial goods like farming and construction equipment, metal and mineral, transport equipment, machinery would gain from TPP agreements. The agreement would help increase Canada's manufacturing and exporting output. The banking sector is also expected to benefit from the deal. Additionally, a significant number of skilled and unskilled employment is likely to generate in Canada.
\end{abstract}

Keywords: Trans-Pacific Partnership agreement, Canada, Global CGE

\section{Introduction}

\subsection{TPP agreement from the Canadian perspective}

The Trans-Pacific Partnership renamed as the Comprehensive and Progressive agreement for Transpacific Partnership (CPTPP) is a proposed free trade agreement involving 12 Asia-Pacific countries (Fergusson et al. 2016). The Trans-Pacific Partnership was developed from the Trans-Pacific Economic Partnership Agreement (P4) between Brunei, Chile, New Zealand and Singapore in 2006. The agreement contains aspects of the past trade agreements on agriculture, forestry, fisheries and industrial goods where tariff reductions and/or eliminations have been negotiated while incorporating new areas such

(c) The Author(s) 2018. This article is distributed under the terms of the Creative Commons Attribution 4.0 International License (http://creativecommons.org/licenses/by/4.0/), which permits unrestricted use, distribution, and reproduction in any medium, provided you give appropriate credit to the original author(s) and the source, provide a link to the Creative Commons license, and indicate if changes were made. 
as electronic commerce. There are currently 11 other countries involved in the partnership apart from Canada, and these are Australia, Brunei, Chile, Japan, Malaysia, Mexico, New Zealand, Peru, Singapore, USA and Vietnam. Decisions on membership are made by the existing members of the partnership. Besides the new trade agreements introduced by the TPP (CPTPP), these agreements will coexist with existing free trade agreements. TPP is a living agreement which makes it possible for membership to be expanded to include other countries. It also has an extensive coverage (Lakatos et al. 2016).

Canada has a number of free trade agreements with some TPP members, including the USA and Mexico under the NAFTA, as well as Chile and Peru under the CanadaChile and Canada-Peru FTAs. The TPP agreement formulates new FTAs with seven Asian nations-Australia, Brunei, Dar-es-Salaam, Japan, Malaysia, New Zealand, Singapore and Vietnam. Canada's bilateral trade is marginal with these seven partners except with Japan - the third largest economy in the world.

The agreement is expected to be a platform for future trade agreements which benefit the economies of participating countries by liberalizing trade and investment. The partnership also incorporates new areas and agreements that go beyond those existing in the World Trade Organisation (Fergusson et al. 2016). These agreements are different from the traditional trade agreements because they incorporate cooperation on difficult trade policy issues such as regulatory barriers which have been complex to tackle so far. TPP makes this possible (Lakatos et al. 2016). Different countries have market access for different goods and services. The negotiations were concluded in 2015, but the final agreement was signed in 2016.

Ratification would create the largest trade zone in the world, spanning four continents and 800 million people. Table 1 shows the GDP contribution of TPP member nations in 2013(27.5 Trillion USD), its scope accounts for 40\% of the world's economic output. The share of Canada's trade with TPP countries other than the USA is $11 \%$. Despite the presence of many barriers to trade, Canada's exports to TPP countries averaged $\$ 366.1$ billion CAD annually from 2012 to 2014. Industrial goods comprise the major portion of

Table 1 GDP of TPP member countries and Canada's total trade with TPP countries (in million USD) in 2013. Source: World Bank, Canadian Council of Chief Executives

\begin{tabular}{lllr}
\hline GDP in billion USD & Country & $\begin{array}{l}\text { Canada's total trade } \\
\text { with TPP countries }\end{array}$ & $\begin{array}{c}\text { Share of Canada's trade } \\
\text { across TPP nations }\end{array}$ \\
\hline 1827 & Canada & - & 0.51 \\
1560 & Australia & 3451 & 0.00 \\
16 & Brunei & 31 & 0.38 \\
277 & Chile & 2555 & 3.59 \\
4920 & Japan & 24,393 & 0.44 \\
313 & Malaysia & 2962 & 4.73 \\
1261 & Mexico & 32,113 & 0.13 \\
185 & New Zealand & 910 & 0.54 \\
202.3 & Peru & 3682 & 0.34 \\
297.9 & Singapore & 2274 & 89.29 \\
166,910 & USA & 606,022 & 0.38 \\
171.4 & Vietnam & 2571 & 100 \\
$27,721.7$ & Total & 678,690 & \\
\hline
\end{tabular}


exports, i.e. $\$ 311.4$ billion $\mathrm{CAD}$, followed by agriculture and agri-food (\$30.9) and forestry and wood products $(\$ 20.4)$.

TPP countries get duty-free access to 3.25 and $2.1 \%$ of Canada's dairy and poultry market, respectively.

Over time, tariffs among members of the TPP would be eliminated for a number of products, thus lowering trade barriers significantly even for countries which apply high tariffs to particular products. It also seeks to enhance the development of supply chains which involve careful coordination of production decisions, rules on shipping, investment and the transfer of information among different countries. TPP incorporates social, labour and environmental standards such as standards that address illegal wildlife trafficking and logging and strengthen copyright terms which is likely to have an impact on trade and production chains (Lakatos et al. 2016). Some of the agreements of the TPP by the Canadian government are for the elimination of tariffs on products such as pork, fruits, canola, machinery and minerals; increased mobility of high skilled and business workers; increased import of foreign car parts and the compensation of losses faced by farmers under the TPP through a series of multibillion dollar programmes such as quota protection, modernizing equipment and marketing assistance.

Throughout the implementation of the Trans-Pacific Partnership and the CanadianEU Trade Agreement, the government of Canada has introduced a number of initiatives for producers and processors. For instance, the income guarantee programme, quota value guarantee programme, market development initiative and processor modernization programme have been introduced by the government to support supply-managed producers and processors. These initiatives are to provide income protection for producers, promote marketing of top quality goods and encourage competitiveness and growth.

Rules, custom procedures and technical standards put in place by the TPP decreases production cost for farmers and also makes it easier for countries to transact business among each other. By being a part of the TPP negotiations, Canada can put forth proposals that will be in their best interest and therefore influence the rules that govern trade relationships (Dawson and Bartucci 2013). Generally, the TPP agreements lead to better trade which results in greater competition, efficiency in productivity, lower prices, restraining inflation and making diverse goods and services available to consumers. Overall, Canada will benefit from improved market access for food, meat, fish, alcohol products, industrial products, metals and minerals and also the services sectors. This occurs through the strengthening of partnership with existing trade partners and access to markets in Asia. Besides expansion, Canada will benefit from trade and investment diversification, since most of its exports are skewed towards the USA and scarcely any to countries such as Mexico, Peru and Chile. This expansion and diversification in trade and investment will lead to an increase in the market presence in these and other countries such as Australia, New Zealand and Vietnam and result in the growth in Canada's exports. TPP is expected to cover approximately $80 \%$ of Canada's exports after all the partners come on board. Participating in this partnership is important for Canada because most of the TPP members are wealthy growing economies with younger population who would be interested in purchasing goods and services that Canada can offer such as financial services, energy, education and technology. TPP will increase Canada's integration with other fast growing Asian markets and economies. TPP is likely to 
reduce risk and uncertainty for exporters and investors in the long run (Dawson and Bartucci 2013).

Canada benefits from the TPP agreement in numerous ways. Canada is expected to have a country-specific quota in Japan for wheat which starts at 40,000 tonnes and increases to 53,000 tonnes within 6 years. It will also have access to a TPP-wide quota for food barley starting from 25,000 to 65,000 tonnes within 8 years. The TPP agreement will lead to a reduction or elimination of existing taxes on processed food and nonalcoholic beverages (maple syrup, baked goods, sugar and chocolate confectionery) in countries such as Japan and Vietnam where Canada's export of these products face high tariffs. This will be highly beneficial to the Canadian economy since the agricultural and agri-food industry is a key processing sub-sector which contributed approximately $\$ 27.7$ billion to the country's economy in 2013 (Global Affairs Canada, Govt. of Canada).

Within 2 years (2012-2014), Canada's export of canola oil to TPP countries, largely to Japan, totalled $\$ 1.8$ billion annually. In the same period, Canada's export of processed food and non-alcoholic beverages to TPP countries was, on average, $\$ 7.3$ billion annually.

The TPP agreement will improve the market access opportunities for the wines and spirits sector in Canada through the removal of tariffs in countries such as Japan, Vietnam, Australia and New Zealand. In Vietnam and Australia, duties up to 55 and 5\%, respectively, on whisky will be eliminated within 12 years of the agreement coming into force. Streamlined processes at the border and trade facilitating rules such as the elimination of tariffs up to $16.8 \%$ on sweetened dried cranberries in Japan could lead to an increase in Canadian exports. The market access for fish and seafood such as frozen snow crab, herring roe, lobster, shrimps, scallops, mussels and salmon will also be improved with the elimination of tariffs in Japan, Malaysia and Vietnam.

The TPP agreement improves Canada's industrial trade to Australia, Japan, New Zealand and Malaysia. The industries include those of wood and related products, industrial goods, metals and minerals, chemicals and plastics, ICT and life science products, machines and equipment and cosmetics. For instance, the two way investment between Canada and Australia was valued at $\$ 30.3$ billion in 2014. In the automobile industry, TPP provides access into new markets where free trade agreements did not exist for Canada. This will be made possible through the elimination of tariffs for all vehicles and vehicle parts into TPP market and also through better access for Canadian automotive exports to Vietnam and Malaysia. The integration between the Canadian and the North American auto industry is also protected and strengthened as a result of the agreement. Examples of Canadian metals and minerals that will benefit from tariff elimination are aluminium products, iron and steel, petroleum products. Also, plastic bags, plates, pipes and sheets are examples of Canadian exports of chemicals and plastics that will benefit from tariff elimination. Tariffs up to approximately 17,4 and $20 \%$, respectively, in Vietnam, Japan and Malaysia will be eliminated upon the TPP agreement coming into force.

New opportunities for Canada's aerospace sector will be enhanced through the TPP agreement by providing considerable certainty for the exports of aerospace-related goods and services. This would be achieved through the implementation of rules that promote non-discrimination and transparency in government procedures and also demonstrate Canada's production realities and methods. These agreements will further promote transparent cross-border trade services as well as temporary entry of business 
persons which will improve the market access for professional services, research and development, environmental, construction and transportation services. New commitments have been assured for particular high skilled professionals and technicians from Australia, Brunei, Peru, Chile and Mexico. Under the TPP agreement, tariff elimination on industrial machinery such as compressors and pumps, agricultural machinery, such as harvesters and movers, and construction equipment, such as lifting, loading, handling, moving and grading machinery, will generate export opportunities for high-quality Canadian machinery.

In addition to these benefits, the TPP provides commitments that go further than trade agreements made by the World Trade Organisation and Canada's free trade agreements with several members of the TPP agreement, such as, market access for environmental services in Vietnam and Malaysia. Canada also benefits from voluntary deliberations of mutual recognition agreements between its authorities and their counterparts in TPP countries and from the access to free data which is made available through the transparent framework of the TPP. Discrimination against Canadian service suppliers is diminished or eliminated in TPP markets making it easier for them to provide their services freely in different countries.

The agreement promotes the participation of Canadian financial companies in the TPP market which increases the potential for growth in the financial sector. This is due to the fact that the agreement protects existing investments, deals with discriminatory barriers to entry into the market, encourages competition and communication among financial regulators, creates transparency in regulatory regimes and enables policymakers to protect the interests of consumers of financial services. Canada will therefore gain from improved investment protection, protection against expropriation and violation of minimum standards of treatment and enhanced ability to transfer funds abroad. It is worth noting that Canada's existing policies for protecting and sustaining the country's cultural context are protected under the TPP. It is expected that TPP member countries which includes Canada will have their GDP increase by $0.4-10 \%$ by 2030 after implementation of the TPP. This increase will be due to tariff cuts in goods and services (Lakatos et al. 2016). It could result in annual income gains of $\$ 9.9$ billion and increased exports of $\$ 15.7$ billion for Canada (Dawson and Bartucci 2013).

On 23 January 2017, Donald Trump signed a presidential memorandum confirming the US withdrawal from the Trans-Pacific Partnership. Canada's potential economic gains from the TPP agreement depend on the participation of the USA-under the TPP agreement. There are a number of issues that would potentially influence Canada's existing economic ties with the USA when the TPP agreement comes into force.

Most importantly, Canada already has preferential market access to the USA and Mexico under NAFTA. Liberalization of the US and Mexican markets for other TPP members would erode the preferences that Canada currently enjoys under the NAFTA, resulting in a displacement of Canada's exports to the USA and Mexico. Canada's preference in the US market would be partially offset by the gains from the new FTA countries under the TPP agreement; however, the importance and size of the US market for Canada's trade might not be significant enough to offset the losses in the US market. ${ }^{1}$

${ }^{1}$ The US' NAFTA-plus commitments under the TPP (i.e. in sugar and services) help to offset these losses. 
Similarly, Canada's trade with new FTA partners under the TPP would likely displace US and Mexican exports to Canada. As a result, Canada's bilateral trade with existing FTA partner countries is expected to decline under the TPP agreement. Net Canadian exports to the existing FTA partner countries would drop by US $\$ 1.5$ billion, largely due to an erosion of NAFTA preferences in the USA and Mexico, while imports from these partner countries will also decline by US $\$ 4.3$ billion (Global Affairs Canada 2016). The sector that will be affected the most is the automotive sector. With more than $80 \%$ of Canadian automotive production exported to the USA, Canadian automotive production will experience a decline. Overall, Canadian exports of automotive products to the USA are projected to decline by US $\$ 3.6$ billion, or a $4.7 \%$ decline in total Canadian automotive product exports to the USA (Global Affairs Canada 2016).

Another important issue under the trade agreement is Rules of Origin (ROO). The ROO requirement is set at a lower rate in the TPP as compared to NAFTA rules. ${ }^{2}$ Under NAFTA, the rules of origin threshold for preferential treatment for assembled vehicles is $62.5 \%$, while under the TPP the threshold is $45 \%$. This lower requirement has important consequences across countries. This means that, under the TPP, automakers have the possibility to source a greater proportion of auto parts from countries outside of the agreement than is currently the case under NAFTA. This is expected to translate into efficiency gains for Canadian automotive producers, but, on balance, would result in losses in both production and investment in the automotive industry (2\% approx.). This is primarily driven by reduced US demand for Canadian automotive parts as US automotive producers are able to source more parts from non-TPP members, thereby displacing Canadian exports to the USA.

Furthermore, US commitments under the TPP for sugar and services are likely to provide new opportunities beyond NAFTA to expand Canadian exports to the US market. The professional services and exports of sugar products would increase considerably.

Given the size of the US economy, the USA plays a pivotal role among TPP members and their participation in the agreement is needed for the full benefit of the TPP agreement to be reached. To realize its full effect, the deal would have to be ratified by February 2018 by at least 6 countries with $85 \%$ of global economic output. The USA would need to be on board to meet the last condition. Some countries, including New Zealand, have suggested some sort of alternative deal may be possible without the USA. But Japan is not as hopeful.

Some studies have investigated the TPP impact on member and non-member countries; however, there are few studies focusing on Canada. World Bank (2016) shows that the TPP agreement could raise member country GDP by an average of $1.1 \%$ by 2030 and increase trade by $11 \%$ over the same period. To the extent that the agreement has positive spillovers to non-members, and detrimental effects through trade diversion and preference erosion could be limited. World Bank (2016) estimated the overall impact of the TPP on member and non-TPP member countries; however, they did not analyse the impact from a single country perspective in general and Canada in particular. Even

\footnotetext{
${ }^{2}$ In order to be eligible for tariff preferences under a regional trade agreement, goods need to satisfy the applicable rules of origin, which set out how much production must be undertaken in a region in order for a good to be considered 'originating'. This is to ensure that the preferential tariff treatment accrues to member countries only.
} 
though the study used a dynamic CGE model, the tariff reduction strategy is different from this study. Further, the selection of sectors is more appropriately addressed in the current study using the actual tariff reduction announcement in the agreement. Further, the study added another simulation exercise where the developing member countries experience input augmenting technical changes due to the likely development of production networks within the region. A descriptive study by Dawson and Bartucci (2013) shows that annual income gains and increases in exports will be $\$ 9.9$ billion and $\$ 15.7$ billion for Canada. However, the TPP does not offer Canada strong market access gains in the short term; instead, the agreement is important for a series of strategic and defensive reasons. Global Affairs Canada (2016) assesses the potential economic impact of the Trans-Pacific Partnership agreement (TPP) on the Canadian economy. They attempted two scenarios: the first had Canada joining the TPP as a member and the second, did not have Canada joining the TPP. The study shows a net advantage to Canada resulting from increased market access and greater regional economic integration with Asia-Pacific countries, if the nation joins TPP. If Canada chooses to remain outside the TPP agreement, this would present several risks to Canada's economic well-being, which could lead to total GDP losses of approximately $\$ 5.3$ billion. The study objective was quite different than the current study. Moreover, all the above studies considered the TPP agreement in its original form when the USA was one of the negotiating countries. There is no study which discussed the impact of TPP on Canada excluding USA, to the best of our knowledge.

Given this context, it is essential to study the TPP impact on the Canadian economy with and without the USA as a member. The study evaluates the economy wide impact of the TPP agreement on Canada and other member countries including the USA in terms of output growth, export, import, income and welfare. The study also attempted another similar exercise without the USA. Further, it attempts two different types of simulations including tariff reductions and technological upgradation.

The remainder of the paper is organized as follows.

Section 2 provides a description of the calibration of the global CGE model that was developed for the study. This includes the data and aggregation strategy. Section 3 explains the experimental design of the scenarios. The analysis of results of the study is presented in Sect. 4. Section 5 concludes the paper with policy recommendations.

\section{Method of analysis}

The multiregional CGE modelling framework that has been used to undertake the analysis of the current study is produced by the Center for Global Trade Analysis at Purdue University, USA. The database and model was developed for the Global Trade Analysis Project (Hertel 1997) and is essentially a multi-country multi-commodity model. The structure of the GTAP model is specified and described in Hertel (1997) and Mukhopadhyay and Thomassin (2009). The model includes industrial sectors, households, governments and global sectors across countries where countries and regions in the model are connected by trade. Prices and quantities are generated simultaneously in both factor markets and commodity markets.

The model employs Leontief production functions and a constant return to scale (CRS) technology to produce final commodities in perfectly competitive markets. Firms 
minimize input costs for given levels of output and fixed technology. In the derivation of factor input demands, the model structure uses constant returns to scale technology and nested constant elasticity of substitution (CES) production functions with three levels to determine the firms' demand for primary and intermediate inputs. Intermediate input bundles are formed through a combination of imported goods and domestic goods. GTAP uses the Armington assumption to distinguish between domestic and foreign goods.

In the GTAP model, each region or composite region has a single representative household that collects all the regional income. The household behaviour is described by an aggregate utility function. The household will purchase a bundle of commodities to maximize its utility subject to given budget constraints. The consumption behaviour is described by a Constant Difference Elasticity Demand System.

Demand is assumed to equal supply in all markets, which are considered to be competitive. This implies equality between the price received by the producer and the producer's marginal cost. Regional governments can intervene in their own markets by imposing taxes and subsidies on commodities and primary factors, thus driving wedges between prices paid by purchasers and prices received by producers (Mukhopadhyay and Thomassin 2009). These policy interventions are modelled as ad valorem taxes, tariffs and subsidies, or quantitative restrictions in case of trade. Thus, these policies have a direct impact on the production and consumption sectors in the model.

Transportation and global banking are two global sectors in the model. The transportation sector accounts for the difference in prices of a commodity as a result of the international freight of the goods transported between countries, and global banking brings global saving and investment into equilibrium.

Another general feature of the model is its explicit recognition of savings by regional economies. These savings are completely exhausted on investments that are savingsdriven in the model. Investment in each region is financed from a global pool of savings where each region contributes a fixed proportion of its income to the savings pool (Mukhopadhyay and Thomassin 2009). In each region, there are five primary factors: skilled labour, unskilled labour, capital, land and natural resources. The total supply of labour and land are fixed in the model. Factor markets are competitive, with labour and capital being mobile between sectors but not between countries. In the standard GTAP model, the mobile endowment commodities are perfectly mobile across industries within each region; and the sluggish endowment commodities are imperfectly mobile, with the degree of mobility governed by an elasticity of transformation function in the GTAP model. In the standard data base, the five labour categories, as well as capital, are mobile, and land and natural resources are sluggish. This is suitable for long-run simulations (Aguiar et al. 2016).

A standard GTAP model selects its exogenous variables such that there is full employment in the factor markets. This is a neoclassical approach whereby the endowments of the productive factors are fixed allowing the market prices to adjust so as to maintain full employment. But the simulations conducted in this study replace this assumption of full employment with existence of unemployment for unskilled labour force for all TPP regions under consideration. This is done by swapping the fixed endowment of unskilled labour with fixed real wage of unskilled labour. 
In equilibrium, all firms have zero real profit, all households adhere to their budget constraint, and global investment equals global savings. Changing the model's parameters allows one to estimate the impact from a country's/region's original equilibrium position to a new equilibrium position resulting from the policy scenario under consideration.

Variables in the model are classified as being either endogenous or exogenous variables. For the model to be solved, the number of endogenous variables must be equal to the number of equations in the model. ${ }^{3}$

The current study was designed to aid in an investigation of the impact of the TPP agreements on the Canadian economy under different scenarios. Thus, the model is appropriate for the study of the consequences on the Canadian economy. The interdependence of the world economy and the comprehensiveness of the GTAP framework is appropriate for the purpose of the study.

\subsection{Data and aggregation}

The study uses the GTAP version 9 database, which uses 2011 as the base year (Narayanan et al. 2012). This version of the model includes 140 regions (countries) and 57 commodities (sectors).

The 140 regions are aggregated to 13 regions with an emphasis on TPP member countries. The 13 countries (regions) include Oceania (Australia and New Zealand), Japan, Vietnam, Brunei, Malaysia, Singapore, Canada, USA, Mexico, Latin America TPP countries (Chile, Peru), non-TPP ASEAN, Rest of OECD ${ }^{4}$ and Rest of the World. The 57 industry sectors have been aggregated to 28 sectors on the basis of trade intensiveness of Canada.

Further, the study uses the labour data from ImpactECON. Documentation of this data source can be found in Walmsley and Carrico (2013).

\subsection{Modifications of the GTAP model}

In order to undertake the desired projection and simulation exercises, a decision was made that the static GTAP model with a base year of 2011 had to be updated to the projection year 2030. For the purposes of model updating, this study uses the recursiveupdating process that is based on forecasting the countries' (regions') economies by exogenously shocking the baseline model with projections of macroeconomic variables. The first step in the modelling process is the generation of a Business as Usual (BAU) projection from the benchmark 2011 GTAP 9 database. New economies can be generated for the years 2011-2030 using macroeconomic shocks for the key variables. The exogenous macrovariable shocks include capital, population, skilled labour, unskilled labour and total factor productivity.

The projection of growth rate for total factor productivity for non-agricultural sectors is sourced from CEP II (Fouré et al. 2010). The growth rate for total factor productivity for the agricultural sectors is based on the estimation work of Ludena et al. (2007). The

\footnotetext{
3 The detail framework of the model is attached as Additional file 1.

4 The Rest of OECD is separated from the Rest of the World because of their distinct development stages that may influence their trade relationships and specific composition of trade with TPP members.
} 
population growth rate projection was taken from the United Nations (2012) Revised Population database, United Nation, Population Division. The growth rates for skilled labour, unskilled labour and for capital are also taken from CEP II (Fouré et al. 2010). GDP is endogenously determined to accommodate the combination of these exogenous shocks.

\section{Scenario development}

The present study simulates various trade integration scenarios between Canada and the TPP countries at 2030. These simulations include the following scenarios described below.

Scenario 1-This BAU scenario projection is developed to provide a picture of how the global economy and world trade might look with the current tariff barriers. Taking 2011 as the base year and using macroeconomic shocks to generate a new economy for 2030. It provides a baseline against which a comparison may be made for the implementation of the various scenarios under study such as the implementation of import tariff reductions and technological upgradation.

It is well known that the simple MFN tariff for Canada is very low compared to other TPP members. The average tariffs applied to Canadian exports by other TPP members in 2014 are given below. This rate provides insight into Canada's expected additional trade with TPP members. Due to the TPP agreements, this rate will be zero. Figure 1 shows that Canada will have a fair chance to increase its trade volume with Vietnam, Chile and Malaysia, if TPP works in full scale.

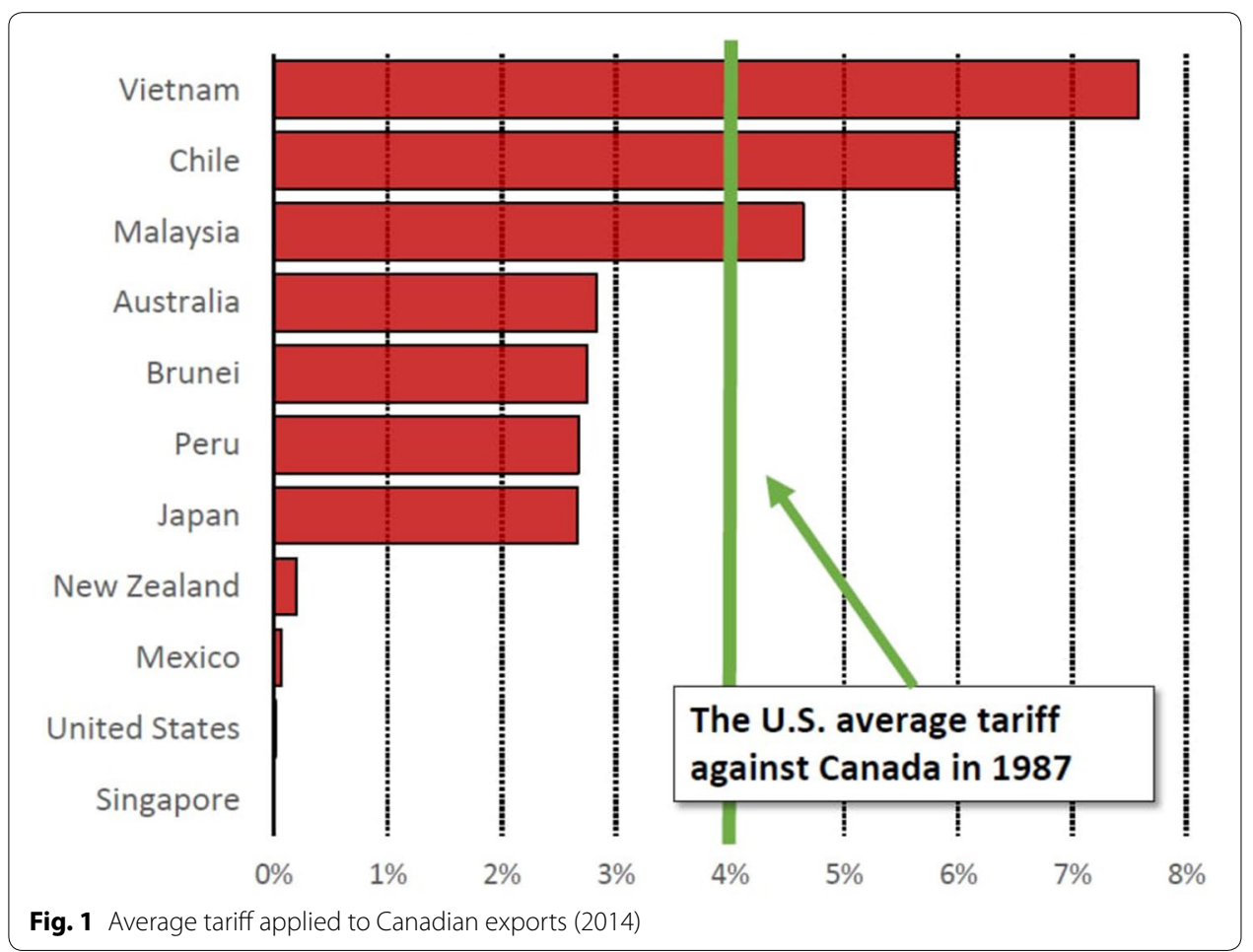


In that direction, we formulated two basic scenarios given below for Canada and other TPP members.

Scenario 2-Import tariff reduction by other TPP members while trading with Canada in 2030 .

Scenario 3-Import tariff reductions by Canada while trading with other TPP members in 2030 .

For Scenarios 2 and 3, the existing tariffs on goods between Canada and other member countries are eliminated completely.

In this exercise, tariff reductions by each of the TPP members, which is applied to Canada and vice versa, are done by considering some selected sectors. The sectors are identified only after checking the tariff commitments proposed in the tariff reduction schedules of each of the members (TPP Tariff Schedules, Office of the United States Trade Representative) and also on the basis of the trade intensiveness between each of the TPP ASEAN countries with other TPP members. The TPP tariff commitments comprise more than 100,000 tariff lines and more than 400 pages of tariff-rate quota (TRQs) commitments for various products including agriculture, industry and manufacturing. These tariff lines and TRQs were carefully formulated to fit within the GTAP sector framework, and all of these data points were incorporated into our assessment.

Another exercise (Scenario 4) was also estimated. It is input augmenting technical change applied to the selected sectors. Figure 2 shows the contribution of intermediate inputs in exports and imports. It covers approximately $70 \%$ of Canada's trade. Towards that end, the current simulation aims to capture the impact of developing production and supply chain integration within the TPP region. The goods traded extensively as inputs between the members are identified and the countries using these inputs

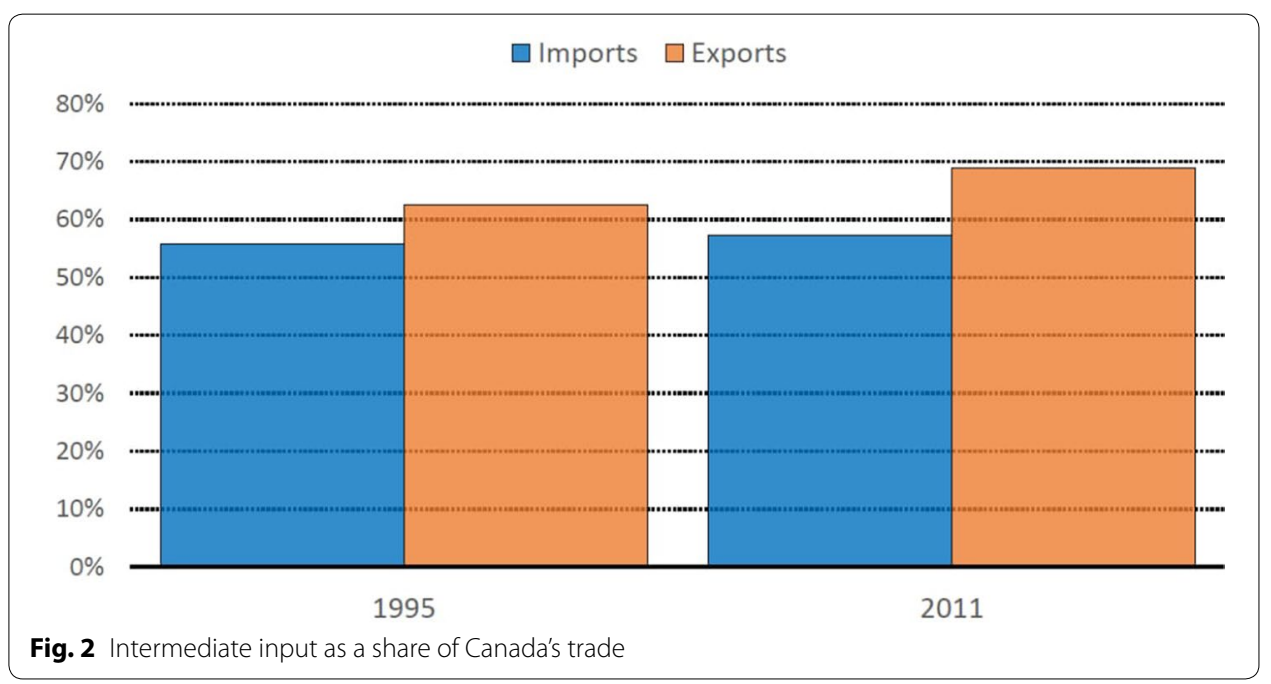


experience input augmenting technical change. ${ }^{5}$ The input augmenting technical change scenario is simulated for the developing countries ${ }^{6}$ of the TPP region for the sectors in which the importing developing countries register an increase in imports of inputs from the developed members of the region. Here we consider only Canada because our study looks at the impact on Canada. This simulation represents a situation where production networks develop among the countries of the region where each country supplies inputs ${ }^{7}$ to the other depending on its comparative advantage and the importing country experiences a technological improvement due to such input imports or development of supply/production chains. However, the import of inputs from any country may not result in technological improvement in the importing country. But it is more likely that import of inputs from the advanced developed countries may lead to technological advancement in developing countries. In fact, there is strong evidence of developing countries relying largely on import of technologies from developed countries for driving their technological change. Thus, the present study considers the import of inputs by TPP members particularly the developing countries, from Canada, a TPP member (as a developed nation) and considers a technological change to the extent of $25 \%$ in the sectors using these imported inputs.

Scenarios 2 through 4 are separated into two sub-scenarios, i.e. the USA continues to be part of the TPP and the USA is not part of the TPP deal.

\section{Analysis of results}

In this section, we discuss the responsiveness of each scenario with respect to output, export, import, household income and welfare from the Canadian perspective. Table 2 in "Appendix" provides the total and sectoral output growth at 2030 compared to BAU 2030 due to tariff reduction (Scenarios 2 and 3) and input augmenting technology growth (Scenario 4) with USA as a TPP member. The sectors selected for these scenarios are on the basis of the tariff reductions by different TPP member countries.

\subsection{Output}

The total output growth in Canada is expected to increase by $0.48 \%$ in response to tariff reduction by other TPP member countries. The tariff reduction by other TPP members

\footnotetext{
${ }^{5}$ Rosenberg (1983) has stressed how the technical improvements are often tied to capital goods such as machinery and equipment and therefore the purchase of these goods is fundamental for technical change having an effect on productivity. Capital goods, or machinery, have some characteristics that make them an important vehicle of technology transmission. Capital goods have been historically manufactured in a small number of countries because they require mature stage of industrialization, technical competencies and high skill (Rosenberg 1983). Moreover, capital goods industry is highly specialized and requires a large market Capital production has been concentrated in OECD countries, especially in the USA, the UK and Germany. These countries are also among the most R\&D intensive. It follows that the machinery produced in these countries can be expected to be particularly knowledge intensive and therefore to have a higher potential for the transfer of technology. As for the impact of capital goods on productivity machinery are among the possible sources of economic growth and technological progress (Jaffe et al. 2005). Rosenberg (1963, 1983) describes how capital good industry has generated most of the aggregate technological progress. The main beneficiaries of improvement in machinery production are the buyers of these machines, as machinery is not final goods, but intermediate inputs used almost all other sectors of the economy.

${ }^{6}$ As per International Monetary Fund classification, the twelve countries of the TPP region are classified into developed and developing countries as follows: Developed-Australia, Canada, Japan, New Zealand, Singapore and the USA and Developing-Brunei Darussalam, Chile, Malaysia, Mexico, Peru and Vietnam.

7 New intermediate inputs play a central role in many trade and growth models. These models predict that firms benefit from international trade through their increased access to previously unavailable inputs, and this process generates static gains from trade. Access to these new imported inputs in turn enables firms to expand their domestic product scope through the introduction of new varieties, which generates dynamic gains from trade. Despite the prominence of these models, we have surprisingly little evidence to date on the relevance of the underlying microeconomic mechanisms (Goldberg et al. 2010).
} 
enhanced the scope for Canadian export to other TPP nations. The case is valid when USA is participating. From a sectoral perspective, the largest increases are recorded in other food products, beverages and tobacco sector, animal products and fishing (8.63, 4.18 and $3.10 \%$, respectively). Most of the service sectors show a positive output growth, however, marginal. Gain in total output in these sectors may be associated with the increasing level of exports of these sectors resulting from the tariff reduction by the other TPP members. It may be that the exports of some sub-sectors included in the sector (say, other food products, beverages and tobacco) have increased resulting from tariff reductions by the other TPP members, leading to an increase in sectoral output.

At the same time, there is also a nominal decrease in some sectors output such as light manufacturing and electronic equipment sectors. Canada has overall lower levels of tariff protection than most of its TPP members (WTO). Hence, holding other conditions constant, liberalization under TPP should provide a net advantage for Canada.

As per Scenario 3, Canada's own output is adversely affected by tariff reduction, marginally. There is an overall expected decrease of $0.27 \%$. In this scenario, the scope of Canadian imports is expanded. However, growth in output has increased in a few sectors. Leather product's sector shows an increase of $1.13 \%$. Other sectors which show improvement are vegetable, fruits and nuts at $0.19 \%$, wood products sector at $0.42 \%$, chemicals, rubber and plastics sector at $0.61 \%$, miscellaneous manufacturing at $0.94 \%$. Decline is recorded highest in other food products, beverages and tobacco at $4.68 \%$, animal products and fishing products sector at 1.53 and $1.52 \%$, respectively.

Considering the case of technological upgradation in Scenarios $4,{ }^{8}$ an overall increase of output was $5.52 \%$. The sector that records highest growth is again other food products, beverages and tobacco sector at $42.75 \%$. It is followed by fishing sector and animal products sector at 21.22 and $15.75 \%$, respectively. Apart from that, a substantial positive output growth is expected from light and heavy manufacturing sector such as wood products (15.14), chemical rubber and plastics (2.15), mineral products (3\%), machinery and equipment, miscellaneous manufacturing and all services sectors. Various other sectors have a decline in output trend are crops and cereals at $2.06 \%$, vegetables, fruits and nuts at $0.73 \%$, textile and apparel at $6.93 \%$ and leather products at $9.81 \%$.

Table 3 in "Appendix" discusses the scenarios for tariff reduction and technological upgradation without USA as TPP member. It is observed that the positive trend of sectoral output growth remains the same as in the table. The only difference is the magnitude of the output growth which is less in case of 'without USA' scenario when compared to participation of USA as TPP member. In case of Scenario 2, an overall increase of $0.372 \%$ of output growth for Canada is seen with tariff reduction by other TPP members. The highest increase is seen in other food products, beverages and tobacco at $5.6 \%$. Other sectors that show an increase are animal products at $2.015 \%$, fishing at $2.717 \%$ and construction at $0.5725 \%$. In addition, all service sectors in general also show a positive impact. However, a marginal decrease (less than 1\%) is found in electronic equipment, forestry, paper products, coal and other minerals, metal products and miscellaneous manufacturing.

${ }^{8}$ Scenario 4 applies technological upgradation on selected sectors only. 
In case of Scenario 3, with tariff reduction, there appears to be an overall decrease in output of $0.18 \%$. A marginal decline in output growth is seen in other food products, beverages and tobacco, animal products and fishing (ranges between 1 and 2\%). There is also an increase in some sectors, the highest being in leather products at $0.76 \%$, vegetable, fruits and nuts at $0.12 \%$, oil and gas, paper products, electronic equipment and iron, steel and non-metallic mineral products.

With technological upgradation, Scenario 4 shows an overall increase of $2.94 \%$. The sector that recorded the highest increase is miscellaneous manufacturing at $22.11 \%$. Other sectors that record an increase in output are chemicals, rubber and plastic by $2.9 \%$, construction by $2.48 \%$, forestry by $4.55 \%$ and other food products, beverages and tobacco by $5.55 \%$ and wood products by $12.8 \%$.

The overall observation from the scenarios developed with USA as a TPP member shows a higher output growth for most of the sectors compared to the scenarios without USA. Further, most of the scenarios result in more output growth in the agri-food sector, industrial products, metals and minerals and services sectors.

\subsection{Exports}

Table 4 in "Appendix" explains the export growth in 2030 for all scenarios with USA as a TPP member. Considering Scenario 2 with tariff reductions, there is an overall increase in exports by $0.26 \%$. The highest increase would be witnessed in other food products, beverages and tobacco at $39.4 \%$. The other sector which shows an increase is the animal products sector and metal products, chemical, rubber and plastics. Some important sectors show a decline in exports. The largest decline is seen in leather products at $3.06 \%$. Other decreases include $1.9 \%$ for other crops and $1.73 \%$ for vegetable oils and fats.

Scenario 3 also shows an overall increase of $0.91 \%$, with the highest increase in other food products, beverages and tobacco at $4.08 \%$. Other sectors that experience an increase are animal products at $2.93 \%$, transport equipment at $1.10 \%$, electronic equipment at $1.44 \%$ and construction at $0.62 \%$. In Scenario 3, there is no decrease in exports in any sector.

This implies that the country's reduction in tariff lines in various goods might have increased imports, but it has also helped to boost the country's exports.

In case of technological upgradation, Scenario 4 witnesses an average increase of $5.21 \%$. The highest increase is reported in miscellaneous manufacturing at $43.46 \%$. Other sectors that experience an increase are electronic equipment at $16.35 \%$, chemicals, rubber and plastic at $7.35 \%$, transport equipment at $9 \%$, wood products at $37 \%$ and animal products at $7.98 \%$. However, some of the sectors noticed a decrease in exports such as the paper products and forestry sectors. Other sectors which show a marginal decline are the oil and gas sector, construction and services sector.

The general trend of the sectoral export growth is similar to the output growth. Agriculture and agri-food sectors are dominating all scenarios. Apart from that, electronic equipment, chemical rubber and plastic, machinery equipment, mineral products and transport equipment are also showing an increase in exports.

As a result of the TPP agreement, Canadian exports to the new TPP countries would increase considerably. The country-specific results show that the most significant new export opportunities exist in Japan, because it is a major trading partner of Canada and Canadian exports are expected to increase for animal products and wood products in 
particular. Among other TPP members, Canada is also expected to see an increase in exports to Oceania countries, ${ }^{9}$ Vietnam and Malaysia. These export gains are expected from machinery and equipment and transport equipment exports to Oceania and Malaysia, as well as exports of other food products, beverages and tobacco and automotive products to Vietnam.

Table 5 in "Appendix" provides the export growth changes in 2030 compared to BAU for all scenarios without USA as a TPP member. In case of Scenario 2, with tariff reductions, there is an overall increase of $0.20 \%$. The highest increase is in iron and steel and non-metallic mineral products sector at $7.75 \%$. Other sectors that experience an increase are animal products at $4.43 \%$ and fishing at $0.38 \%$. Apart from these, most of the sectors have a decline in exports. Sectors that follow the declining trend are crops and cereals, chemicals, rubbers and plastic, other crops, textiles and apparel, miscellaneous manufacturing and electronic equipment.

In case of Scenario 3, with tariff reductions, there is a decrease of $0.03 \%$ on average. The sector with the largest decline is other food products, beverages and tobacco, followed by vegetables, fruits and nuts. Other sectors such as animal products, forestry, chemicals, rubber and plastic record a decline of $0.44,0.04$ and $1.11 \%$, respectively. There is also an increase in some sectors, for example crops and cereals by $1.51 \%$. Other sectors which show an increase are other crops at $3.63 \%$ and other services at $0.24 \%$.

Evaluating the technological upgradation case, i.e. Scenario 4, there was an overall increase in exports of $4.10 \%$. The highest increase is seen in miscellaneous manufacturing at $59.16 \%$. Other sectors with large increases are animal products at $10.31 \%$, chemical, rubber and plastics sector at $15.89 \%$ and wood products at $45.56 \%$. Other sectors experience a marginal decline such as the mineral sectors and services. Most sectors experience a positive response in this scenario.

\subsection{Imports}

In case of import growth, Scenario 2 reveals that there is an overall increase of $0.20 \%$ (Table 6 in "Appendix"). The highest increase is recorded in the textile and apparel sector at $38.67 \%$. Other sectors that record an increase are leather products at $11.48 \%$, mineral products at $15.08 \%$, metal products at $8.44 \%$, miscellaneous manufacturing at $10.47 \%$, electronic equipment at $15.37 \%$ and construction at $1.24 \%$. Among the sectors that record a decline, the largest decline is $9.77 \%$ in the crops and cereals sector. Other sectors which experience a decline include other crops by $3.38 \%$, fishing by $5.17 \%$, vegetable oils, fats by $7.41 \%$ and wood products by $3 \%$.

Scenario 3, with tariff reductions, records an average increase of $1.88 \%$. The sector with the largest decline is crops and cereals at $9.07 \%$. Other sectors that experience reductions are other crops at $7.44 \%$, oil and gas by $7.73 \%$, vegetable oils and fats by 7.56 . Sectors that record a positive growth are vegetables and nuts with an increase of $3.8 \%$, leather products by $11.5 \%$, mineral products by $14.8 \%$, electronic equipment by $15.18 \%$ and the highest being in the textiles and apparel sector by $38.32 \%$.

In case of technological upgradation, Scenario 4 shows an overall increase of $3.18 \%$. Other sectors which show an increase are: vegetable, fruits and nuts sector by $4.6 \%$,

\footnotetext{
${ }^{9}$ Here Australia and New Zealand is aggregated as OCEANIA TPP.
} 
other food products, beverages and tobacco sector by $5.01 \%$, metal products by $10.6 \%$, miscellaneous manufacturing by $12.17 \%$. The largest increase is in the mineral products sector at $17.65 \%$, machinery and equipment sector at $15.55 \%$ and electronic equipment at $16.81 \%$. Further, the service sectors show a positive impact. There are also sectors which record a decline. Some of them are crops and cereals sector by $8.69 \%$, which is one the largest declines, other crops by $6.99 \%$, fishing by $6.23 \%$, oil and gas by $7.71 \%$, wood products by $3.26 \%$ and paper products by $5.36 \%$.

The country-specific analysis shows that imports from the TPP nations are likely to increase across the scenarios $(2.1,1.88$ and $3.14 \%)$ led by machinery and equipment and miscellaneous manufacturing from Japan and labour-intensive products such as textile and apparel products from Vietnam. However, the increase in imports will be affected to some extent due to a decline in imports from NAFTA countries. Similarly, Canada's trade with new TPP partners would likely displace US and Mexican exports to Canada. As a result, Canada's bilateral trade with existing partner countries is expected to decline under the TPP agreement. Net Canadian exports to the existing FTA partner countries would decline, e.g. to the USA and Mexico, while imports from these partner countries would also decline.

The case for import changes, without the USA, is presented in Table 7. In terms of import changes with tariff reductions in Scenario 2, there is an overall increase of 5.59\%. The sectors which record the largest increase are crops and cereals by $2 \%$, animal products sector by $7.02 \%$, wood products by $13.36 \%$, metal products by $9.40 \%$ and the highest in forestry by $25.64 \%$. At the same time, no sector records a decline. Considering Scenario 3, with tariff reductions, on average there is an increase of $1.48 \%$. Sectors that record an increase are coal and other minerals by 1.08\%, mineral products sector by $1.19 \%$, electronic equipment sector by $4.59 \%$, electricity, gas and water supply by $9.34 \%$, and the largest increase is in the animal products sector by $19.7 \%$. Unlike Scenario 2, there are sectors which record a decrease in output due to import changes. Some of these are crops and cereals sector by $7.63 \%$, fishing sector by $8.67 \%$ which has the largest decline, and vegetable oils and fats sector by $4.19 \%$. With technological upgradation in Scenario 4, there is an overall decrease of $0.89 \%$. The sector which records the largest decline is the fishing sector by $9.04 \%$. Similarly, other sectors which experience declines are the crops and cereals sector by $7.68 \%$, other crops sector by $3.69 \%$ and vegetable oils and fats sector by $4.23 \%$. Sectors which record an increase are textiles and apparel sector by $2.63 \%$, mineral products sector by $1.26 \%$, transport equipment sector by $4.76 \%$, electronic equipment sector by $4.19 \%$ and the largest being recorded in machinery and equipment sector by $6.83 \%$.

The sector that will be affected the most by the erosion of NAFTA preferences is the automotive sector. With more than $80 \%$ of Canadian automotive production exported to the USA, the Canadian automotive production will experience a decline. Overall, Canadian exports of automotive products to the USA are projected to decline by $2.1 \%$ by 2030 as compared to BAU at 2030.

\subsection{Welfare impact}

The welfare decomposition when the USA is a TPP member and the tariff reduction is defined as in Scenario 2 indicates that the allocative efficiency for Canada and the terms 
of trade will improve by $\$ 347$ million and $\$ 1662$ million, respectively (Table 8 ). The global welfare would also increase. Further analysis of the components of welfare change shows that both the allocative efficiency effect and terms of trade effect play an important role in improving the level of welfare. Welfare results in Scenario 2 indicate that Canada would gain in welfare with the increased level of its exports in response to the tariff cut by its trade partners in the TPP. The global welfare is observed to increase as well (Table 10). The results indicate that the increased level of exports and therefore the changing pattern have led to an efficient allocation of resources of the country. The positive terms of trade effect indicate an increase in the relative price of Canada's exports as compared to its imports as a result of the tariff cut by its trade partners in the TPP.

However, the level of welfare was seen to be reduced with the reduction in Canada's own tariff lines (Scenario 3). In Scenario 3, welfare was reduced by $\$ 1231$ million. This occurred because of adverse terms of trade, though the allocative efficiency increased by $\$ 781$ million. Canada gains in welfare due to industry-wide efficient allocation of resources in Scenario 3, but the adverse terms of trade effect result in a net loss in welfare (\$189.57 million). With the reduction in its tariffs, Canada is importing goods which are relatively costlier than its exports. Though the increased level of imports resulting from the tariff cut has helped to boost exports, it has a detrimental impact on the level of welfare of the country. Finally, in Scenario 3 the global welfare is observed to increase (Table 10). In Scenario 4, even though the TOT effect is negative, the total welfare for Canada is expected to be $\$ 22,876$ million.

Table 9 provides the welfare decomposition without the USA in the TPP scenario. The simulations in Scenario 2 indicate that the overall welfare for Canada increases by $\$ 1345.31$ million. At the same time, the allocative efficiency as well as terms of trade improved by $\$ 226.24$ million and $\$ 1137.56$ million, respectively.

Similarly, for Scenario 3, with tariff reduction, the overall welfare declines by $\$ 189.57$ million. However, the terms of trade as well as allocative efficiency increase by $\$ 457.51$ million and $\$ 306.64$ million, respectively. This impact is not strong enough to result in an increase in total welfare, however.

With technological upgradation in Scenario 4 , the total welfare increases by $\$ 16,710$ million. The results indicate that there is positive terms of trade as well as allocative efficiency, with an increase of $\$ 404$ million and $\$ 3538$ million, respectively (Table 9).

Considering the impact of TPP on the various economic variables for Canada, it seems that the country may gain from the tariff reduction by its trade partners in TPP but when it comes to the case of its own tariff reduction, it may experience a loss in overall welfare. The loss is higher in the case of trade with USA as a TPP member as compared to without the USA. Apart from Canada, other TPP member countries show a positive welfare gain with some variations in welfare across countries in all scenarios. However, a welfare loss is expected for non-member countries.

\subsection{Employment generation}

Following the pattern of responses from other variables in the different scenarios, additional jobs (labour force) will be created in Scenarios 2 and 4, while a reduction in the labour force is observed in Scenario 3. The scope of both unskilled and skilled jobs is expected to increase in equal proportion in Scenarios 2 and 4 with an expected increase of 83 thousand and 957 thousand jobs, respectively. An equal share of unskilled and 
skilled job reduction is expected from Scenario 2, i.e. total 46 thousand. Like other variables, the job creation also shows a similar pattern in case of 'with USA' and 'without USA' in the TPP. In the case of the TPP without the USA, Scenarios 1 and 4 are estimated to contribute 64 thousand and 510 thousand additional jobs to the economy. Scenario 2 is likely to reduce 31 thousand jobs. Out of a total of 5 categories of labour, official and managerial jobs are expected to increase the most.

\subsection{Factor income}

In Scenario 2, for tariff reduction, income for unskilled labour is expected to increase by $0.54 \%$. Increases are expected for skilled labour and capital, which increase by 0.59 and $0.61 \%$, respectively (Table 14 ). Scenario 3 , tariff reduction, estimates an increase in factor value for unskilled labour, skilled labour and capital of $0.47,0.36$ and $0.43 \%$, respectively. Scenario 4 with technological upgradation also results in higher factor income compared to other scenarios. For skilled labour, the increase is $2.8 \%$, while unskilled labour increases by $1.9 \%$ and capital had a $5.1 \%$.

When the USA was not part of the TPP, the results for Scenario 2 indicated that there would be a decrease in factor income for skilled labour, unskilled labour and capital of $0.34,0.31$ and $0.39 \%$, respectively (Table 13 ). Similarly for Scenario 3 , there was a decrease of $0.27,0.21$ and $0.25 \%$ for skilled, unskilled and capital, respectively. With technological upgradation, the results indicate that there would be an increase of 1.89 , 1.63 and $1.42 \%$ for skilled, unskilled and capital, respectively.

Given the pattern of change in total output and welfare, the change in household income in Scenarios 2 and 3 was as expected. In Scenario 2, the household income was observed to increase, whereas in Scenario 3 it showed a decline. Similarly, both the skilled and unskilled labour employment increased in Scenario 2 more or less equally, given the increased level of output. Employment increased in animal products, fishing and other food products and beverages sectors. The increased employment in these sectors was expected because of the significant increase in output in Scenario 2. In contrast, both these categories of labour experienced a decline in employment in Scenario 3 with the reduction in total output resulting from Canada's own level of tariff.

\section{Conclusion}

The study uses various scenarios to evaluate the impact of the TPP on the Canadian economy. Three scenarios that included tariff reductions and the technological upgradation were analysed. The variables considered were output, exports, imports, welfare decomposition and factor income. The entire exercise considered two types of simulations: one with the USA as a member of the TPP and the other without the USA in the TPP.

The total and sectoral output growth in the case of 'with USA' is higher when compared to 'without USA' across all three scenarios. When the USA was in the TPP scenarios, technological upgradation provided the greatest output growth across sectors and the total as well; however, there were variations within sectors.

Similar trends were observed in exports; however, tariff reductions by other TPP members (Scenario 1) generated scope for Canada to export more. This was apparent in both simulations. Canada is expected to benefit in terms of output, exports, imports, welfare and factor income, if the USA participates in the TPP agreement. 
The technological upgradation scenario is quite promising for Canada. It is known that firms that expand their intermediate input imports expand the volume and scope of their exports. Further, the literature suggests that the benefit of imported inputs differs along a number of dimensions including initial trade status, import source country, export destination, firm ownership and industry R\&D intensity (Li and Whalley 2012).

The welfare decomposition affirms a positive impact except in Scenario 3. This applies to both simulations - with and without US participation. However, the impact is strongest in both cases with US participation. The technological upgradation reveals that for both scenarios welfare increased with US participation. In the case when the USA did not participate, the welfare levels were still positive. The results indicate that the overall welfare was much higher with US participation. Further, the global welfare is expected to increase across all scenarios and the two simulations.

Analysing the impact on factor income for unskilled labour, skilled labour and capital, the results indicate that there would be a decline without US participation in Scenario 3 of tariff reduction. Apart from this scenario, all other scenarios resulted in positive growth. When the USA is in the TPP, having technological upgradation results in a considerable increase in all factor incomes. A significant number of skilled and unskilled labour employment are generated in Scenarios 2 and 4.

TPP goes far beyond classic trade liberalization which favours Canada; however, the challenge is to ensure that the benefits from trade diversification are captured. The largest gains are expected in the automotive sector. Exports to non-TPP countries are mainly mineral fuel, minerals, machinery, agriculture and agri-food and chemical rubber plastic, while imports are restricted to machinery and vehicle, agriculture and agrifood, clothing, etc. Further, Canada's exports to the USA are approximately $77 \%$ of its total exports. Given the extensive trade relations between the USA and Canada, having the USA in the TPP, the results indicate that the changes follow the same trend in both scenarios but vary in magnitude. When the USA is not in the TPP, the magnitude of the positive impact is lower while the magnitude of the negative impact is much larger as compared to when the USA is in the TPP.

Recently, the government of Canada has been diversifying its trading relationships. In September 2017, the Canada European Union Comprehensive Economic and Trade Agreement (CETA) came into force. This trade agreement expands the trading opportunities between Canada and the European Union. The leaders of the 11 countries involved in the TPP met in Vietnam in November 2017 to discuss the TPP negotiations. At the end of the meeting, the leaders were able to say that the core elements of the TPP have been agreed to by all parties. Even in the absence of the USA, Canada and other nations seem to be pursuing new trade agreements as a means of advancing their economic welfare. Currently, Canada, the USA and Mexico are renegotiating the NAFTA agreement. The US president wants to renegotiate the trade deal so that the terms of trade are more in favour of the USA. These new trade endeavours, with the European Union and the 11 countries in the TPP agreement, would indicate that more emphasis is being placed on international trade away from traditional North-South model. Our study results would support a policy that diversifies the trade arrangements that Canada gets involved in. 


\section{Additional file}

Additional file 1. Methodological description.

Authors' contributions

The corresponding author has contributed in designing the research, modelling exercise and drafting the manuscript. Aside from this, both authors have contributed in finalising the manuscript. They have also given final approval of the version to be published. Both authors read and approved the final manuscript.

This is a revised version of the paper presented at the 24th International Input-Output Association conference held at Seoul, Korea, 4-8 July 2016. The authors wish to thank the conference participants for their valuable comments and suggestions.

Author details

${ }^{1}$ Gokhale Institute of Politics and Economics, Pune 411104, India. ${ }^{2}$ Department of Natural Resource Sciences, Agricultural Economics Program, McGill University, Macdonald Campus, 21,111 Lakeshore Road, Ste Anne de Bellevue, Montreal, QC H9X3V9, Canada.

Acknowledgements

Not applicable.

Competing interests

The authors declare that they have no competing interests.

Availability of data and materials

The dataset supporting the conclusions of this article is available in and bought from the GTAP database version 9.

Consent for publication

Not applicable.

Ethics approval and consent to participate

Not applicable.

\section{Appendix}

See Tables 2, 3, 4, 5, 6, 7, 8, 9, 10, 11, 12, 13 and 14. 
Table 2 Sectoral output growth due to tariff simulation and technological upgradation at 2030 compared to BAU 2030 (with USA as TPP member)

\begin{tabular}{|c|c|c|c|}
\hline \multirow[t]{2}{*}{ Sector } & \multicolumn{2}{|c|}{ Tariff reduction } & \multirow{2}{*}{$\begin{array}{l}\text { Technological upgradation } \\
\text { Scenario } 4\end{array}$} \\
\hline & Scenario 2 & Scenario 3 & \\
\hline 1. Crops and cereals & 0.47 & -0.03 & -2.06 \\
\hline 2. Vegetable, fruits and nuts & 0.49 & 0.19 & -0.73 \\
\hline 3. Other crops & -0.47 & 0.30 & -6.52 \\
\hline 4. Animal products & 3.10 & -1.53 & 15.75 \\
\hline 5. Forestry & -0.28 & 0.33 & 8.87 \\
\hline 6. Fishing & 4.18 & -1.52 & 21.22 \\
\hline 7. Oil and gas & -0.22 & 0.10 & -2.55 \\
\hline 8. Coal and other minerals & -0.44 & 0.25 & -2.56 \\
\hline 9. Vegetable oils and fats & 0.37 & 0.21 & -1.99 \\
\hline 10. Other food products, beverages and tobacco & 8.63 & -4.68 & 42.75 \\
\hline 11. Textiles and apparel & -0.66 & -0.42 & -6.93 \\
\hline 12. Leather products & -0.96 & 1.13 & -9.81 \\
\hline 13. Wood products & -0.28 & 0.42 & 15.14 \\
\hline 14. Paper products & 0.05 & 0.06 & 0.09 \\
\hline 15. Petroleum and coal products & -0.05 & 0.03 & 0.43 \\
\hline 16. Chemicals, rubber and plastics & -0.85 & 0.61 & 2.15 \\
\hline 17. Mineral products & 0.29 & -0.05 & 3.01 \\
\hline 18. Iron and Steel and non-metallic mineral products & -1.42 & 0.78 & -2.37 \\
\hline 19. Metal products & -0.27 & 0.27 & -1.18 \\
\hline 20. Transport equipment & -0.91 & 0.59 & -6.33 \\
\hline 21. Electronic equipment & -1.51 & 0.83 & -13.77 \\
\hline 22. Machinery and equipment nec. & -0.04 & -0.01 & 0.30 \\
\hline 23. Miscellaneous manufacturing & -1.39 & 0.94 & 18.64 \\
\hline 24. Electricity, gas and water supply & 0.02 & -0.02 & 2.42 \\
\hline 25. Construction & 0.88 & -0.35 & 9.50 \\
\hline 26. Trade, transport and communication & 0.48 & -0.32 & 5.45 \\
\hline 27. Financial services & 0.36 & -0.24 & 4.07 \\
\hline 28. Other services & 0.48 & -0.35 & 5.54 \\
\hline Total & 0.48 & -0.27 & 5.52 \\
\hline
\end{tabular}


Table 3 Sectoral output growth due to tariff simulation and technological upgradation at 2030 compared to BAU 2030 (without USA as TPP member)

\begin{tabular}{|c|c|c|c|}
\hline \multirow[t]{2}{*}{ Sector } & \multicolumn{2}{|c|}{ Tariff reduction } & \multirow{2}{*}{$\begin{array}{l}\text { Technological upgradation } \\
\text { Scenario } 4\end{array}$} \\
\hline & Scenario 2 & Scenario 3 & \\
\hline 1. Crops and cereals & 0.21 & -0.03 & -1.30 \\
\hline 2. Vegetable, fruits and nuts & 0.32 & 0.13 & -0.82 \\
\hline 3. Other crops & -0.31 & 0.20 & -1.12 \\
\hline 4. Animal products & 2.02 & -1.04 & 2.56 \\
\hline 5. Forestry & -0.18 & 0.22 & 4.56 \\
\hline 6. Fishing & 2.72 & -1.03 & 0.53 \\
\hline 7. Oil and gas & -0.14 & 0.07 & -0.42 \\
\hline 8. Coal and other minerals & -0.29 & 0.17 & -1.15 \\
\hline 9. Vegetable oils and fats & 0.24 & 0.14 & -1.89 \\
\hline 10. Other food products, beverages and tobacco & 5.61 & -3.18 & 5.55 \\
\hline 11. Textiles and apparel & -0.43 & -0.29 & -3.71 \\
\hline 12. Leather products & -0.62 & 0.77 & 0.14 \\
\hline 13. Wood products & -0.18 & 0.29 & 12.81 \\
\hline 14. Paper products & 0.03 & 0.04 & -1.77 \\
\hline 15. Petroleum and coal products & -0.03 & 0.02 & -0.13 \\
\hline 16. Chemicals, rubber and plastics & -0.55 & 0.41 & 3.00 \\
\hline 17. Mineral products & 0.19 & -0.03 & 1.40 \\
\hline 18. Iron and Steel and non-metallic mineral products & -0.92 & 0.53 & 0.73 \\
\hline 19. Metal products & -0.18 & 0.18 & 0.15 \\
\hline 20. Transport equipment & -0.59 & 0.40 & 0.59 \\
\hline 21. Electronic equipment & -0.98 & 0.56 & -11.87 \\
\hline 22. Machinery and equipment nec. & -0.03 & -0.01 & -2.90 \\
\hline 23. Miscellaneous manufacturing & -0.90 & 0.64 & 22.12 \\
\hline 24. Electricity, gas and water supply & 0.01 & -0.01 & -1.29 \\
\hline 25. Construction & 0.57 & -0.24 & 2.49 \\
\hline 26. Trade, transport and communication & 0.31 & -0.22 & 0.20 \\
\hline 27. Financial services & 0.23 & -0.16 & -1.43 \\
\hline 28. Other services & 0.31 & -0.24 & 0.44 \\
\hline Total & 0.37 & -0.18 & 2.94 \\
\hline
\end{tabular}


Table 4 Sectoral export growth due to tariff simulation and technological upgradation at 2030 compared to BAU 2030 (USA as TPP member)

\begin{tabular}{|c|c|c|c|}
\hline \multirow[t]{2}{*}{ Sector } & \multicolumn{2}{|c|}{ Tariff reduction } & \multirow[t]{2}{*}{ Technological upgradation } \\
\hline & Scenario 2 & Scenario 3 & \\
\hline 1. Crops and cereals & -2.14 & 1.12 & 1.15 \\
\hline 2. Vegetable, fruits and nuts & -0.05 & 0.57 & 0.03 \\
\hline 3. Other crops & -1.90 & 0.81 & 0.28 \\
\hline 4. Animal products & 1.21 & 2.93 & 7.98 \\
\hline 5. Forestry & -0.72 & 0.18 & -0.82 \\
\hline 6. Fishing & -1.18 & 1.03 & 2.06 \\
\hline 7. Oil and gas & -0.24 & 0.10 & -0.93 \\
\hline 8. Coal and other minerals & -0.10 & -0.71 & -0.76 \\
\hline 9. Vegetable oils and fats & -1.73 & 1.34 & -0.83 \\
\hline 10. Other food products, beverages and tobacco & 39.40 & 4.08 & 8.59 \\
\hline 11. Textiles and apparel & -2.35 & 1.92 & 0.33 \\
\hline 12. Leather products & -3.06 & 3.06 & 5.10 \\
\hline 13. Wood products & -0.80 & 0.91 & 37.56 \\
\hline 14. Paper products & -1.52 & 0.76 & -4.00 \\
\hline 15. Petroleum and coal products & -0.30 & 0.14 & -0.74 \\
\hline 16. Chemicals, rubber and plastics & -1.53 & 1.03 & 7.35 \\
\hline 17. Mineral products & -1.59 & 0.84 & -3.68 \\
\hline 18. Iron and Steel and non-metallic mineral products & -1.53 & 0.67 & 2.46 \\
\hline 19. Metal products & -2.33 & 1.21 & -2.58 \\
\hline 20. Transport equipment & -1.24 & 1.10 & 9.05 \\
\hline 21. Electronic equipment & -2.80 & 1.44 & 16.35 \\
\hline 22. Machinery and equipment nec. & -2.44 & 1.36 & -2.88 \\
\hline 23. Miscellaneous manufacturing & -2.17 & 1.39 & 43.46 \\
\hline 24. Electricity, gas and water supply & -1.54 & 0.85 & -4.55 \\
\hline 25. Construction & -1.24 & 0.62 & -2.48 \\
\hline 26. Trade, transport and communication & -1.40 & 0.93 & -3.11 \\
\hline 27. Financial services & -1.46 & 0.78 & -4.70 \\
\hline 28. Other services & -1.45 & 0.76 & -4.10 \\
\hline Total & 0.26 & 0.91 & 5.21 \\
\hline
\end{tabular}


Table 5 Sectoral export growth due to tariff simulation and technological upgradation at 2030 compared to BAU 2030 (without USA as TPP member)

\begin{tabular}{|c|c|c|c|}
\hline \multirow[t]{2}{*}{ Sector } & \multicolumn{2}{|c|}{ Tariff reduction } & \multirow{2}{*}{$\begin{array}{l}\text { Technological upgradation } \\
\text { Scenario } 4\end{array}$} \\
\hline & Scenario 2 & Scenario 3 & \\
\hline 1. Crops and cereals & -0.97 & 1.51 & 1.55 \\
\hline 2. Vegetable, fruits and nuts & 0.00 & -9.80 & 0.16 \\
\hline 3. Other crops & -0.88 & 3.63 & 1.26 \\
\hline 4. Animal products & 4.43 & -0.44 & 10.31 \\
\hline 5. Forestry & -0.68 & -0.04 & 0.18 \\
\hline 6. Fishing & 0.38 & 0.67 & 2.01 \\
\hline 7. Oil and gas & -0.16 & 0.03 & -0.53 \\
\hline 8. Coal and other minerals & -0.07 & 0.35 & -0.57 \\
\hline 9. Vegetable oils and fats & -0.75 & 0.08 & -0.04 \\
\hline 10. Other food products, beverages and tobacco & -0.62 & -13.58 & -3.01 \\
\hline 11. Textiles and apparel & -1.45 & 6.68 & 1.15 \\
\hline 12. Leather products & -1.91 & 1.26 & 2.11 \\
\hline 13. Wood products & -0.97 & 0.49 & 45.56 \\
\hline 14. Paper products & -0.59 & 0.24 & -1.28 \\
\hline 15. Petroleum and coal products & -0.19 & 0.03 & -0.21 \\
\hline 16. Chemicals, rubber and plastics & -3.31 & -1.11 & 15.89 \\
\hline 17. Mineral products & -0.99 & 0.16 & -0.66 \\
\hline 18. Iron and Steel and non-metallic mineral products & 7.75 & 1.08 & 6.33 \\
\hline 19. Metal products & -1.49 & -0.02 & 0.03 \\
\hline 20. Transport equipment & -0.35 & 0.83 & 6.81 \\
\hline 21. Electronic equipment & -1.72 & 0.75 & 8.46 \\
\hline 22. Machinery and equipment nec & -1.30 & -0.45 & 0.94 \\
\hline 23. Miscellaneous manufacturing & -2.95 & -1.43 & 59.16 \\
\hline 24. Electricity, gas and water supply & -0.95 & 0.29 & -1.57 \\
\hline 25. Construction & -0.79 & 0.10 & -0.42 \\
\hline 26. Trade, transport and communication & -0.87 & 0.32 & -1.06 \\
\hline 27. Financial services & -0.91 & 0.29 & -1.75 \\
\hline 28. Other services & -0.91 & 0.24 & -1.32 \\
\hline Total & 0.20 & -0.03 & 4.10 \\
\hline
\end{tabular}


Table 6 Sectoral import growth due to tariff simulation and technological upgradation at 2030 compared to BAU 2030 (USA as TPP member)

\begin{tabular}{|c|c|c|c|}
\hline \multirow[t]{2}{*}{ Sector } & \multicolumn{2}{|c|}{ Tariff reduction } & \multirow{2}{*}{$\begin{array}{l}\text { Technological upgradation } \\
\text { Scenario } 4\end{array}$} \\
\hline & Scenario 2 & Scenario 3 & \\
\hline 1. Crops and cereals & -9.77 & -9.07 & -8.695 \\
\hline 2. Vegetable, fruits and nuts & 4.72 & 3.892 & 4.604 \\
\hline 3. Other crops & -3.38 & -7.446 & -6.993 \\
\hline 4. Animal products & -6.88 & -5.72 & -2.81 \\
\hline 5. Forestry & -9.1 & -6.902 & -6.181 \\
\hline 6. Fishing & -5.17 & -5.977 & -4.148 \\
\hline 7. Oil and gas & -7.733 & -7.73 & -7.713 \\
\hline 8. Coal and other minerals & -7.306 & -7.262 & -7.33 \\
\hline 9. Vegetable oils and fats & -7.416 & -7.565 & -6.896 \\
\hline 10. Other food products, beverages and tobacco & 2.827 & 3.389 & 5.014 \\
\hline 11. Textiles and apparel & 38.676 & 38.325 & 42.638 \\
\hline 12. Leather products & 11.486 & 11.558 & 12.244 \\
\hline 13. Wood products & -3.448 & -3.536 & -2.373 \\
\hline 14. Paper products & -5.424 & -5.51 & -4.849 \\
\hline 15. Petroleum and coal products & 1.341 & 1.358 & 1.52 \\
\hline 16. Chemicals, rubber and plastics & 1.05 & 0.997 & 1.811 \\
\hline 17. Mineral products & 15.08 & 14.802 & 17.658 \\
\hline 18. Iron and Steel and non-metallic mineral products & -3.793 & -3.726 & -3.531 \\
\hline 19. Metal products & 8.447 & 8.244 & 10.684 \\
\hline 20. Transport equipment & 0.505 & 0.476 & 0.923 \\
\hline 21. Electronic equipment & 15.377 & 15.188 & 17.02 \\
\hline 22. Machinery and equipment nec. & 12.644 & 12.211 & 15.833 \\
\hline 23. Miscellaneous manufacturing & 10.474 & 10.335 & 12.171 \\
\hline 24. Electricity, gas and water supply & -6.642 & -6.696 & -6.192 \\
\hline 25. Construction & 1.24 & 1.095 & 2.335 \\
\hline 26. Trade, transport and communication & 2.674 & 2.48 & 3.943 \\
\hline 27. Financial services & 5.2 & 4.976 & 6.721 \\
\hline 28. Other services & 0.653 & 0.502 & 1.735 \\
\hline Total & 2.011 & 1.88 & 3.18 \\
\hline
\end{tabular}


Table 7 Sectoral import growth due to tariff simulation and technological upgradation at 2030 compared to BAU 2030 (without USA as TPP member)

\begin{tabular}{|c|c|c|c|}
\hline \multirow[t]{2}{*}{ Sector } & \multicolumn{2}{|c|}{ Tariff reduction } & \multirow{2}{*}{$\begin{array}{l}\text { Technological upgradation } \\
\text { Scenario } 4\end{array}$} \\
\hline & Scenario 2 & Scenario 3 & \\
\hline 1. Crops and cereals & 2.08 & -7.63 & -7.68 \\
\hline 2. Vegetable, fruits and nuts & 0.36 & -1.15 & -1.12 \\
\hline 3. Other crops & 1.78 & -3.65 & -3.69 \\
\hline 4. Animal products & 7.02 & 19.7 & 9.17 \\
\hline 5. Forestry & 25.64 & -0.26 & -0.26 \\
\hline 6. Fishing & 0.4 & -8.67 & -9.04 \\
\hline 7. Oil and gas & 1.19 & 0.06 & 0.06 \\
\hline 8. Coal and other minerals & 2.93 & 1.08 & 1.09 \\
\hline 9. Vegetable oils and fats & 4.11 & -4.19 & -4.23 \\
\hline 10. Other food products, beverages and tobacco & 5.19 & 2.06 & 3.51 \\
\hline 11. Textiles and apparel & 5.55 & 2.44 & 2.63 \\
\hline 12. Leather products & 4.57 & 0.3 & 0.3 \\
\hline 13. Wood products & 13.36 & 1.42 & 1.31 \\
\hline 14. Paper products & 7.89 & 0.6 & 0.59 \\
\hline 15. Petroleum and coal products & 1.95 & -0.06 & -0.06 \\
\hline 16. Chemicals, rubber and plastics & 5.86 & 1.05 & 1.32 \\
\hline 17. Mineral products & 7.41 & 1.19 & 1.26 \\
\hline 18. Iron and Steel and non-metallic mineral products & 7.05 & 1.62 & 1.58 \\
\hline 19. Metal products & 9.4 & 0.72 & 0.76 \\
\hline 20. Transport equipment & 3.18 & 2.45 & 4.76 \\
\hline 21. Electronic equipment & 4.59 & 3.78 & 4.19 \\
\hline 28. Machinery and equipment nec & 9.22 & 5.36 & 6.83 \\
\hline 23. Miscellaneous manufacturing & 6.84 & 1.09 & 1.15 \\
\hline 24. Electricity, gas and water supply & 9.34 & 1.07 & 1.05 \\
\hline 25. Construction & 6.25 & 0.55 & 0.7 \\
\hline 26. Trade, transport and communication & 6.57 & 0.87 & 1.01 \\
\hline 27. Financial services & 6.47 & 1.08 & 1.2 \\
\hline 28. Other services & 6.65 & 1.05 & 1.86 \\
\hline Total & 5.59 & 1.48 & -0.89 \\
\hline
\end{tabular}

Table 8 Welfare impact on Canada in million USD (with USA as a TPP member)

\begin{tabular}{lccr}
\hline & Allocative efficiency & Terms of trade & Total \\
\hline Scenario 2 & 347 & 1662 & 1994 \\
Scenario 3 & 781 & -1231 & -453 \\
Scenario 4 & 9011 & -1087 & 22,876 \\
\hline
\end{tabular}

Table 9 Welfare impact on Canada in million USD (without USA)

\begin{tabular}{llll}
\hline & Allocative efficiency & Terms of trade & Total \\
\hline Scenario 2 & 226.24 & 1137.56 & 1345.31 \\
Scenario 3 & 306.64 & 457.51 & -189.57 \\
Scenario 4 & 3538 & 404 & 16,710 \\
\hline
\end{tabular}


Table 10 Total welfare impact of the other TPP members and Rest of the World in million USD (with USA)

\begin{tabular}{lccc}
\hline & Scenario 2 & Scenario 3 & Scenario 4 \\
\hline 1 Oceania TPP & -28 & 51 & 3553 \\
2 Brunei & 1 & -1 & 20.6 \\
3 Malaysia & 2 & -2 & 1018 \\
4 Singapore & -10 & 3 & 218 \\
5 Vietnam & -42 & 191 & 1768 \\
6 Japan & -231 & 295 & 10,150 \\
7 Canada & 1994 & -453 & 22,876 \\
8 USA & -830 & 2070 & 2387 \\
9 Mexico & 18 & -85 & 687 \\
10 Latin American TPP Countries & -35 & -16 & 1437 \\
11 Non-TPP ASEAN & -90 & -104 & -1509 \\
12 Other OECDCS & -225 & -611 & -3589 \\
13 Rest of the World & 79 & -630 & -2033 \\
Total & 604 & 710 & 36,765 \\
\hline
\end{tabular}

Table 11 Total welfare impact of the Other TPP members and Rest of the World (without USA)

\begin{tabular}{lrcc}
\hline & Scenario 2 & Scenario 3 & Scenario 4 \\
\hline 1. Oceania TPP & -30.92 & 37.75 & 2452 \\
2. Brunei & 0.87 & -0.74 & -3.54 \\
3. Malaysia & 2.17 & -1.09 & 1247 \\
4. Singapore & -10.16 & 1.59 & -116 \\
5. Vietnam & -57.01 & 122.61 & 1135 \\
6. Japan & -245.69 & 219.78 & 7562 \\
7. Canada & 1345.31 & -189.75 & 16,710 \\
8. USA & 1966.34 & 2414.75 & -8192 \\
9. Mexico & 25.78 & -41.05 & -356 \\
10. Latin American TPP Countries & -40.85 & 23.13 & 144 \\
11. Non-TPP ASEAN & -70.56 & -63.73 & -565 \\
12. Other OECDCs & -181.31 & -271.87 & -1597 \\
13. Rest of the World & 94.00 & -385.61 & -2755 \\
Total & 361.07 & 275.70 & 15,668 \\
\hline
\end{tabular}


Table 12 Additional labour force generation in different scenarios with USA (in thousand)

\begin{tabular}{lrlr} 
Scenario 1 & & & \\
1. Technicians & 14.90 & Unskilled & 41.38 \\
2. Clerks & 14.20 & Skilled & \\
3. Service/shop workers & 14.24 & \\
4. Officials and mangers & 27.02 & \\
5. Agricultural and unskilled & 12.94 & \\
Total & 83.30 & & \\
Scenario 2 & & Unskilled & \\
1. Technicians & -8.38 & Skilled & \\
2. Clerks & -7.99 & & \\
3. Service/shop workers & -8.01 & \\
4. Officials and mangers & -15.20 & \\
5. Agricultural and unskilled & -7.28 & \\
Total & -46.86 & \\
Scenario 3 & & Unskilled \\
1. Technicians & 171.40 & Skilled \\
2. Clerks & 163.29 & \\
3. Service/shop workers & 163.80 & \\
4. Officials and mangers & 310.69 & \\
5. Agricultural and unskilled & 148.76 & \\
Total & 957.94 & \\
\hline
\end{tabular}

Table 13 Additional labour force generation in different scenarios without USA (in thousand)

\begin{tabular}{lrll}
\hline Scenario 1 & & & \\
1. Technicians & 11.49 & Unskilled & 31.90 \\
2. Clerks & 10.95 & Skilled & 32.31 \\
3. Service/shop workers & 10.98 & \\
4. Officials and mangers & 20.83 & \\
5. Agricultural and unskilled & 9.97 & & \\
Total & 64.21 & Unskilled & -15.52 \\
Scenario 2 & & Skilled & -15.72 \\
1. Technicians & -5.59 & & \\
2. Clerks & -5.32 & \\
3. Service/shop workers & -5.34 & \\
4. Officials and mangers & -10.13 & \\
5. Agricultural and unskilled & -4.85 & Unskilled \\
Total & -31.24 & Skilled \\
Scenario 3 & & & 253.44 \\
1. Technicians & 91.29 & \\
2. Clerks & 86.97 & \\
3. Service/shop workers & 87.24 & \\
4. Officials and mangers & 165.48 & \\
5. Agricultural and unskilled & 79.23 & \\
Total & 510.21 & \\
\hline
\end{tabular}


Table 14 Change in factor income for the Canadian economy (\%)

\begin{tabular}{llll}
\hline & $\begin{array}{l}\text { Tariff reduction } \\
\text { Scenario 2 }\end{array}$ & $\begin{array}{l}\text { Tariff reduction } \\
\text { Scenario 3 }\end{array}$ & $\begin{array}{l}\text { Technological } \\
\text { upgradation Scenario 4 }\end{array}$ \\
\hline With USA & & & \\
Unskilled labour & 0.54 & 0.27 & 2.8 \\
Skilled labour & 0.59 & 0.36 & 1.9 \\
Capital & 0.61 & 0.43 & 5.1 \\
Without USA & & & 1.89 \\
Unskilled labour & 0.34 & -0.27 & 1.63 \\
Skilled labour & 0.21 & -0.21 & 1.42 \\
Capital & 0.39 & -0.25 & \\
\hline
\end{tabular}

\section{Publisher's Note}

Springer Nature remains neutral with regard to jurisdictional claims in published maps and institutional affiliations.

Received: 18 April 2017 Accepted: 29 November 2017

Published online: 24 January 2018

\section{References}

Aguiar A, Narayanan B, McDougall R (2016) An overview of the GTAP 9 data base. J Glob Econ Anal 1(1):181-208

Dawson L, Bartucci S (2013) Canada and the Trans-Pacific Partnership: entering a new era of strategy trade policy. Fraser Institute, Vancouver

Fergusson IF, McMinimy AM, Williams RB (2016) The Trans-Pacific Partnership (TPP): in brief. Congressional Research Service, Washington

Fouré J, Bénassy-Quéré A, Fontagné L (2010) The world economy in 2050: a tentative picture. CEPII Working Paper, No. 27 Global Affairs Canada (2016) Economic impact of Canada's potential participation in the Trans-Pacific Partnership agreement, Office of the Chief Economist, Government of Canada. http://international.gc.ca/economist-economiste/ analysis-analyse/tpp_ei-re_ptp.aspx?lang=eng. Accessed Mar 2016

Global Trade Analysis Project, Purdue University (2016) GTAP databases 9. https://www.gtap.agecon.purdue.edu. Accessed Feb 2015

Goldberg PK, Khandelwal AK, Pavcnik N, Topalova P (2010) Imported intermediate inputs and domestic product growth: evidence from India. Q J Econ 125(4):1727-1767

Hertel TW (ed) (1997) Global trade analysis: modeling and applications. Cambridge University Press, New York

Jaffe AB, Newell RG, Stavins RN (2005) A tale of two market failures: technology and environmental policy. Ecol Econ 54(2-3):164-174

Lakatos C, Maliszewska M, Ohnsorge F, Petri P, Plummer M (2016) Potential macroeconomic implications of Trans-Pacific partnership. In: Global economic prospects: spillovers amid weak growth. A World Bank Group flagship report, Chap 4. The World Bank, Washington DC, pp 219-234

Li C, Whalley J (2012) China and the TPP: a numerical simulation assessment of the effects involved. NBER Working Paper No. 18090, Cambridge

Ludena CE, Hertel TW, Preckel PV, Nin A (2007) Productivity growth and convergence in crop, ruminant and non-ruminant production: measurement and forecasts. Agric Econ 37(2007):1-17

Mukhopadhyay K, Thomassin PJ (2009) Economic and environmental impact of free trade in east and south east Asia. Springer, Berlin

Narayanan BG, Aguiar A, McDougall R (2012) Global trade, assistance, and production: the GTAP 7 data base. In: Center for global trade analysis. Purdue University, West Lafayette

Rosenberg N (1963) Capital goods, technology, and economic growth. Oxf Econ Pap 15(3):217-227

Rosenberg N (1983) Inside the black box: technology and economics. Cambridge University Press, Cambridge

TPP tariff schedules, TPP Full Text, Office of the United States Trade Representative. http://ustr.gov/trade-agreements/ free-trade-agreements/trans-pacific-partnership/tpp-full-text. Accessed April, 2016

United Nations (2012) United Nations publication, revised population database, United Nation, population division. http://www.un.org/en/development/desa/population/publications/database/index.shtml. Accessed Feb 2015

Walmsley TL, Carrico C (2013) Disaggregating labor payments in the GTAP 8 data base. GTAP Application, Center for Global Trade Analysis, Purdue University, West Lafayette

World Bank (2016) Highlights from Chapter 4 potential implications of the Trans-Pacific Partnership, Global Economic Prospects. http://pubdocs.worldbank.org/en/287761451945044333/Global-Economic-Prospects-January2016-Highlights-Trans-Pacific-Partnership.pdf. Accessed Feb 2017 